CARPATHIAN JOURNAL OF FOOD SCIENCE AND TECHNOLOGY

journal homepage: http://chimie-biologie.ubm.ro/carpathian_journal/index.html

\title{
THE EFFECT OF THE DRYING AND EXTRACTION METHODS ON THE PECTIN YIELD AND THE OPTIMIZATION OF MICROWAVE-ASSISTED PECTIN EXTRACTION FROM KAFFIR LIME (CITRUS HYSTRIX) POMACE
}

\author{
Suthida Akkarachaneeyakorn $^{1 *}$ Ampika Jakkornraksa ${ }^{1}$ Pongpat Komprapai $^{1}$ and \\ Pitchaporn Tulthanakarn ${ }^{1}$ \\ ${ }^{I}$ Department of Agro-Industrial, Food, and Environmental Technology, Faculty of Applied Science, \\ King Mongkut's University of Technology North Bangkok (KMUTNB), \\ 1518 Pracharat I Road, Wongsawang, Bangsue, Bangkok 10800, Thailand \\ *suthida.a@sci.kmutnb.ac.th
}

https://doi.org/10.34302/crpifst/2019.11.3.16

\begin{abstract}
Article history:
Received:

20 March 2018

Accepted:

10 August 2019

Keywords:

Box-Behnken design;

Extraction methods;

Kaffir lime pomace;

Microwave-assisted;

Pectin yield.
\end{abstract}

\begin{abstract}
This research aimed to determine the effect of the drying methods (hot air oven and microwave oven) and extraction methods (water bath and microwave oven) on the pectin yield from kaffir lime (Citrus hystrix) pomace. The optimal conditions for pectin extraction were studied, and the equation for predicting the pectin yield was determined. The drying method did not significantly affect the pectin yield, but the extraction method did significantly affect the yield. The pectin yield from kaffir lime pomace extracted with a microwave oven $(34.07 \%)$ was 1.5 times higher than that extracted with a hot air oven $(22.32 \%)$. For the determination of the optimal conditions for the microwave-assisted pectin extraction from kaffir lime pomace, a Box-Behnken design was used with 3 factors at 3 levels, including the solid to liquid ratio ( 1 to 12,1 to 30 , and 1 to $48 \mathrm{~g} / \mathrm{mL}$ ), the $\mathrm{pH}(1,1.5$, and 2 ), and the microwave irradiation time (10, 20, and $30 \mathrm{~min})$. The optimal

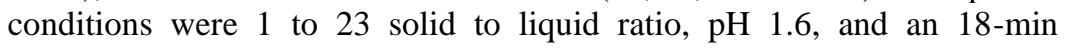
irradiation time with the microwave power at $450 \mathrm{~W}$, which resulted in a yield of $29.21 \%$. The equation for the prediction of the pectin yield was obtained from fitted experimental data $\left(\mathrm{R}^{2}=0.93\right)$. The chemical properties of pectin extracted from the optimal conditions included the moisture content, ash content, equivalent weight, methoxyl content, anhydrouronic acid content and esterification level, which were $9.57 \%, 2.85 \%, 526.87 \mathrm{~g}$, $10.46 \%, 92.79 \%$ and $64.00 \%$, respectively.
\end{abstract}

\section{Introduction}

Pectin is a heteropolysaccharide polymeric compound that confers structure on the primary plant cell wall. The primary structure results from a polymer of galacturonic acids linked by $\alpha-1,4$-glycosidic bonds. Pectin is used as an ingredient in many foods. It has been used as a gelling agent in jams and jellies, a stabilizing agent in dairy products and yogurt, and a thickener in sauces, seasonings, heavy syrups, dressings, drinks, etc. (Thakur et al., 1997; Sila et al., 2009). In addition to its direct use as a food ingredient, pectin is also used as an edible fiber in the form of dietary supplements for health effects such as reducing cholesterol and blood sugar levels (Voragen et al., 1995; Koseki, et al., 1986).

In studies by Wang et al., 2007; Li et al., 2012; Maran et al., 2013; Maran et al., 2014; Thirugnanasambandham et al., 2014; Maran et al., 2015; and Maran and Prakash, 2015, 
pectin was extracted from apple pomace, sugar beet pulp, orange peel, Citrullus lanatus fruit rind waste, dragon fruit peel, mango peel waste, and Carcia papaya L. peel waste by drying the raw material in a hot air oven and extracting the pectin in a microwave oven. The effects of the type of acid (i.e., hydrochloric or sulfuric acid), the $\mathrm{pH}(1-4)$, the solid to liquid ratio, (1 to $5-1$ to 30 by weight to volume), the microwave power (150-640 W), and pectin extraction time in a microwave oven (1-17.4 min) on the yield were studied. The highest pectin yield of $25-29 \%$ was obtained from mango peel waste, Citrullus lanatus waste, fruit rind waste, and Carcia papaya L. peel waste. The optimum conditions for pectin extraction were between 400-477 W power in a microwave oven, a 2-20 min of extraction time, a $\mathrm{pH}$ adjusted with hydrochloric acid to between $1.8-2.7$, and $1 \mathrm{~g}: 15 \mathrm{~mL}$ to $1 \mathrm{~g}: 24 \mathrm{~mL}$ solid to liquid ratio (Maran et al., 2014; Maran et al., 2015; Maran and Prakash, 2015). Pectin was extracted from orange peel and apple pomace at a yield of $19 \%$ and $16 \%$, respectively. The optimum extraction conditions were a microwave power of 400$500 \mathrm{~W}$, a 2-3 min extraction time, a $\mathrm{pH}$ adjusted with hydrochloric acid to 1.5-2.7, and a $1 \mathrm{~g}: 15 \mathrm{~mL}$ to $1 \mathrm{~g}$ : $20 \mathrm{~mL}$ solid to liquid ratio (Wang et al., 2007; Maran et al., 2013). Pectin extracted from the dragon fruit peel had the lowest yield of $7 \%$.

No research has studied the effect of drying samples in a hot air oven or a microwave oven and the effect of pectin extraction in a water bath or a microwave oven on the pectin yield from kaffir lime pomace, nor has any research studied the optimum conditions for pectin extraction from kaffir lime pomace in terms of yield. The anticipated benefits from such research are a lower cost of kaffir lime pomace disposal, which would add value to that agricultural waste and methods that would enhance the efficiency of pectin extraction in terms of yield. Therefore, this study aimed to determine the effect of drying kaffir lime pomace in either a hot air oven or a microwave oven and investigate the effects of a pectin extraction method by a water bath or a microwave oven on the pectin yield. The drying and extraction methods for pectin from kaffir lime pomace that produced the highest yield were chosen to conduct the optimization of pectin extraction. In addition, we also determine of the optimum conditions and the equation to predict the pectin yield for pectin extraction from kaffir lime pomace, and the physical and chemical quality of the extracted pectin were compared with commercial pectin.

\section{Materials and methods}

\subsection{Raw materials}

Kaffir lime (Citrus hystrix) was purchased from the Nonthaburi Market, Mueang, Nonthaburi, Thailand, weighed $37 \pm 3 \mathrm{~g}$, was approximately 6 months old, and had a dark green peel.

\subsection{Kaffir lime pomace preparation}

The kaffir limes were cut in half, and the skin was peeled to get rid of the essential oils. They were then squeezed to remove the juice, and the seeds were also removed. The kaffir lime pomace was boiled with $95 \%$ ethanol at a ratio of 1:1 (w/v) in a water bath (WNB 22, Memmert, Germany) with $15 \mathrm{~L}$ of water at 80 ${ }^{\circ} \mathrm{C}$ for $30 \mathrm{~min}$ to eliminate dirt and filtered through a mesh to separate the liquid. The kaffir lime pomace was then squeezed with a squeezing machine to remove the liquid until only the kaffir lime pomace remained.

\subsection{Effect of the drying and extraction method on the pectin yield from kaffir lime pomace}

The kaffir lime pomace was dried in a hot air oven or a microwave oven as detailed in section 2.3.1 and 2.3.2, respectively; then, it was ground with a grinding machine (SK 
100, Retsch, Germany). The dried kaffir lime pomace powder was kept in a zippered polypropylene bag and stored in a desiccator at room temperature until the pectin was extracted. The moisture content of the kaffir lime pomace powder was determined according to an AOAC method (2000). The pectin was extracted in a hot air oven or a microwave oven as detailed in section 2.3.3 and 2.3.4, respectively. The suspension was filtered through a white cloth to separate the liquid from the sludge. The liquid was cooled in a beaker to $40{ }^{\circ} \mathrm{C}$ by immersion in ice water, then set aside. The sludge was extracted twice with distilled water. The $\mathrm{pH}$ was adjusted with hydrochloric acid to the $\mathrm{pH}$ in the first extraction and filtered again. The liquid from both extractions were combined and precipitated with $95 \%$ ethanol at a ratio of $1: 1.5(\mathrm{v} / \mathrm{v})$. The mixture was quickly mixed to accumulate the precipitate, then set aside at room temperature for $1 \mathrm{~h}$, after which it was filtered with a white cloth that was folded twice and placed in a colander. The pectin precipitate was washed with $95 \%$ ethanol three times and dried in a hot air oven (UF 110, Memmert, Germany) at a temperature of $55^{\circ} \mathrm{C}$ for $5 \mathrm{~h}$ until the pectin had moisture content below $12 \%$ as determined by McCready's method (1954). The pectin was then weighed to determine the yield, after which it was ground in a grinding machine (ZM 100, Retsch, Germany).

\subsubsection{Drying kaffir lime pomace in a hot air oven}

The kaffir lime pomace was dried by spreading it evenly in a $18 \times 27 \mathrm{~cm}^{2}$ rectangular tray at $1 \mathrm{~kg}$ per tray, then dried in a hot air oven (UF 110, Memmert, Germany) at $55{ }^{\circ} \mathrm{C}$ for $18 \mathrm{~h}$ to a moisture content of approximately $12 \%$ (dry basis). The experiment was repeated three times.

\subsubsection{Drying kaffir lime pomace in a microwave oven}

Kaffir lime pomace was dried by spreading it evenly in a $18 \times 27 \mathrm{~cm}^{2}$ rectangular tray at $1 \mathrm{~kg}$ per tray, then dried in a microwave oven (MW 7803, SEVERIN, Germany) at $900 \mathrm{~W}$ for $20 \mathrm{~min}$ to a moisture content of approximately 12\% (dry basis). The experiment was repeated three times.

\subsubsection{Pectin extraction from dried kaffir lime pomace in a water bath}

This pectin extraction method was modified from a study by Shaha et al. (2013). Kaffir lime pomace powder (10 g) dried in a hot air oven and a microwave oven as in section 2.3.1 and 2.3.2 was placed in a 1-L beaker and $400-\mathrm{mL}$ of distilled water was added (1:40 weight by volume) The $\mathrm{pH}$ was adjusted with hydrochloric acid to $\mathrm{pH}$ 1.5. The mixture was then extracted in a water bath (WNB 22, Memmert, Germany) containing $15 \mathrm{~L}$ of water at $90{ }^{\circ} \mathrm{C}$ for one hour.

\subsubsection{Pectin extraction from dried kaffir} lime pomace in a microwave oven

The pectin extraction method was modified from a study by Maran et al. (2014) and Shaha et al. (2013). Dried kaffir lime pomace powder $(10 \mathrm{~g})$ obtained as in sections 2.3.1 and 2.3.2 was placed in a 1-L beaker and $400-\mathrm{mL}$ of distilled water was added (1:40 weight by volume). The $\mathrm{pH}$ was adjusted with hydrochloric acid to 1.5 . The mixture was extracted in a microwave oven (MW 7803, SEVERIN, Germany) by placing the beaker in the center of a rotating tray at $450 \mathrm{~W}$ for $20 \mathrm{~min}$.

\subsubsection{Statistical analysis}

The effects of drying and extracting kaffir lime method was studied in an experiment that employed a $2 \times 2$ Factorial Design with three replicates per treatment. An analysis of variance (ANOVA) was performed using the Minitab version 16 software for a two-way ANOVA with two drying methods (hot air and microwave oven) and two extraction methods (water bath and microwave oven). The difference between each treatment mean was compared using Tukey's test at a 95\% confidence level. 
2.4. Determination of the optimum conditions and the equation to predict the pectin yield for pectin extraction from kaffir lime pomace

We found that kaffir lime pomace dried in a hot air oven $\left(55^{\circ} \mathrm{C}, 18 \mathrm{~h}\right)$ had a more uniform moisture content than that dried in a microwave oven ( $900 \mathrm{~W}, 20 \mathrm{~min})$. However, the pectin yield from kaffir lime pomace extracted with a microwave oven $(34.07 \%)$ was 1.5 times higher than that extracted with a hot air oven $(22.32 \%)$. Therefore, we chose drying in a hot air oven and extraction in a microwave oven to conduct experiments to determine the optimum conditions for pectin extraction in terms of yield.

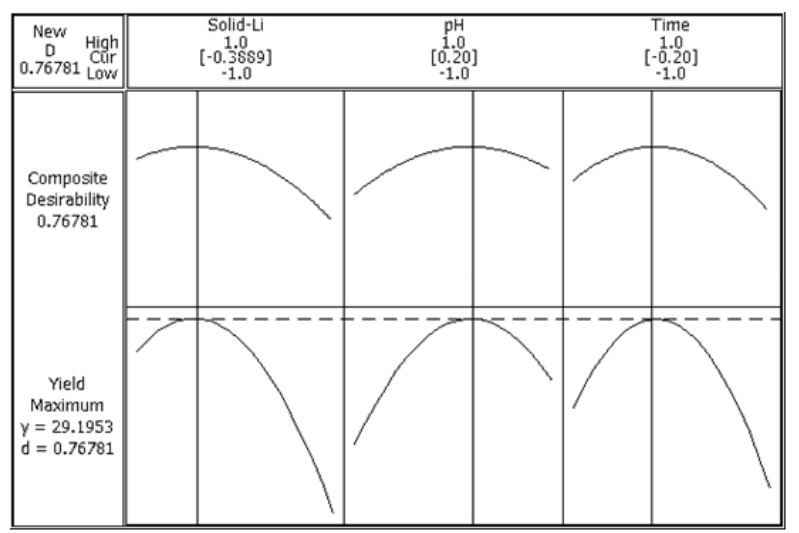

Figure 1. Determination of the optimum conditions for microwave-assisted pectin extraction from pomace using coded values

The extraction procedure was modified from studies by Maran et al. (2014) and Shaha et al. (2013). Dried kaffir lime pomace powder $(10 \mathrm{~g})$ was placed in a $1,000-\mathrm{mL}$ beaker, and distilled water was added according to the ratios in Table 1.

The $\mathrm{pH}$ was adjusted with hydrochloric acid to the $\mathrm{pH}$ values shown in Table 1 . The mixture was then extracted in a microwave oven (MW 7803, SEVERIN, Germany) by placing the beaker in the center of the rotating tray. After the specified time, the suspension was filtered through a white cloth to separate the liquid from the sludge. The liquid was cooled in beaker to $40{ }^{\circ} \mathrm{C}$ by soaking in ice water, then set aside. The separated sludge was extracted twice with distilled water. The $\mathrm{pH}$ was adjusted with hydrochloric acid to the $\mathrm{pH}$ in the first extraction and the extract was filtered again. The liquid from both extractions was combined and precipitated with $95 \%$ ethanol at a ratio of $1: 1.5(\mathrm{v} / \mathrm{v})$. The mixture was quickly mixed to accumulate the precipitate, set aside at room temperature for $1 \mathrm{~h}$, and filtered with a white cloth folded twice and placed in a colander. The pectin precipitates were washed with $95 \%$ ethanol three times, and dried in a hot air oven (UF 110, Memmert, Germany) at a temperature of $55{ }^{\circ} \mathrm{C}$ for $5 \mathrm{~h}$ to moisture content below $12 \%$. The pectin was weighed to determine the yield, then ground with a grinding machine (ZM 100, Retsch, Germany). The physical and chemical properties of the pectin were then determined.

Table 1. Experimental plan for the BoxBehnken Design showing the ratio of kaffir lime pomace powder to distilled water, $\mathrm{pH}$, and the microwave irradiation time for pectin extraction

\begin{tabular}{|c|c|c|c|c|}
\hline \multirow[b]{2}{*}{$\begin{array}{c}\text { Exp. } \\
\text { No. }\end{array}$} & \multicolumn{3}{|c|}{ Factors } & \multirow{2}{*}{$\begin{array}{c}\text { Yield } \\
(\% \\
\text { wet } \\
\text { basis })\end{array}$} \\
\hline & $\begin{array}{c}\text { Ratio of } \\
\text { kaffir } \\
\text { lime } \\
\text { pomace } \\
\text { powder to } \\
\text { distilled } \\
\text { water } \\
(\mathrm{g} / \mathrm{mL})\end{array}$ & $p H$ & $\begin{array}{l}\text { Extraction } \\
\text { time } \\
\text { (min) }\end{array}$ & \\
\hline 1 & $1: 48$ & 2 & 20 & 20.31 \\
\hline 2 & $1: 48$ & 1.5 & 10 & 14.36 \\
\hline 3 & $1: 48$ & 1.5 & 30 & 26.16 \\
\hline 4 & $1: 30$ & 1.5 & 20 & 17.06 \\
\hline 5 & $1: 30$ & 2 & 10 & 26.50 \\
\hline 6 & $1: 30$ & 1 & 30 & 12.62 \\
\hline 7 & $1: 30$ & 1.5 & 20 & 12.38 \\
\hline 8 & $1: 12$ & 1 & 20 & 19.59 \\
\hline 9 & $1: 48$ & 1 & 20 & 17.69 \\
\hline 10 & $1: 12$ & 2 & 20 & 15.90 \\
\hline 11 & $1: 30$ & 1.5 & 20 & 16.16 \\
\hline 12 & $1: 30$ & 1 & 10 & 22.39 \\
\hline
\end{tabular}




\begin{tabular}{|c|c|c|c|c|}
\hline 13 & $1: 12$ & 1.5 & 10 & 30.46 \\
\hline 14 & $1: 30$ & 2 & 30 & 26.68 \\
\hline 15 & $1: 12$ & 1.5 & 30 & 28.33 \\
\hline
\end{tabular}

\subsubsection{Determination of pectin properties}

The physical and chemical properties of the pectin from this study and a commercial food grade pectin (Apple Pectin AP104 HP, China) were determined.

a. The color was measured with a Hunter Laboratory Colorimeter (Color Quest 45/0 Reston, Virginia) by adding $3 \mathrm{~g}$ of pectin powder to a clear plastic container for color measurement, placing it at the measurement spot, closing the lid, and measuring the color at 4 spots 3 times per sample.

b. The moisture content of the kaffir lime pomace powder was determined according to an AOAC method (2000).

c. The moisture content of the pectin was determined according to McCready's method (1954).

d. The amount of ash was determined according to McCready's method (1954).

e. The equivalent weight was determined according to Ranganna's method (1995).

f. The amount of methoxyl was determined according to Ranganna's method (1995).

g. The amount of anhydruronic acid was calculated according to Mohamed and Hasan's method (1995).

$h$. The degree of esterification was calculated according to the method of Owens et al. (1952).

\subsubsection{Statistical analysis}

The Response surface methodology (RSM) using Box-Behnken Design was computed with the Minitab version 16 software for the three factors $x_{1}, x_{2}$, and $x_{3}$ respectively including the ratio of kaffir lime pomace powder to distilled water, the $\mathrm{pH}$, and the pectin extraction time (min) at a constant of microwave power $(450 \mathrm{~W})$. A total of 15 experiments of pectin extraction from kaffir lime pomace using microwave irradiation were done. The experiments at the center point were conducted 3 times and had the experimental order as shown in Table 1. The values used in the experiments had three levels including $-1,0$, and 1 . Both the actual and coded values for the ratio of kaffir lime pomace powder to distilled water, the $\mathrm{pH}$, and the extraction time that are shown in Table 2.

Table 2. Ratio of kaffir lime pomace powder to distilled water, $\mathrm{pH}$, and pectin extraction time from kaffir lime pomace using microwave irradiation that are actual and coded values

\begin{tabular}{|c|c|c|c|}
\hline \multirow{2}{*}{$\begin{array}{c}\text { Coded } \\
\text { value }\end{array}$} & $\begin{array}{c}|c| \\
\text { Ratio of } \\
\text { kaffir lime } \\
\text { pomace } \\
\text { powder to } \\
\text { distilled } \\
\text { water } \\
\text { (g/mL) }\end{array}$ & $\mathbf{p H}$ & $\begin{array}{c}\text { Extraction } \\
\text { time (min) }\end{array}$ \\
\hline-1 & $1: 12$ & 1 & 10 \\
\hline 0 & $1: 30$ & 1.5 & 20 \\
\hline 1 & $1: 48$ & 2 & 30 \\
\hline
\end{tabular}

\section{Results and discussions}

\subsection{Drying and extraction methods to yield}

Two drying methods for the pomace in were studied: a hot air oven at $55^{\circ} \mathrm{C}$ for $18 \mathrm{~h}$ and a microwave at $900 \mathrm{~W}$ for $20 \mathrm{~min}$. The results showed that the drying method significantly $(p<0.05)$ affected the final moisture content of the pomace. The moisture content of the pomace dried in a microwave oven had an mean of $10.61 \%$ (wet basis) or $11.87 \%$ (dry basis), which was significantly higher $(\mathrm{p}<0.05)$ than that dried in a hot air oven with a mean moisture content of $9.26 \%$ (wet basis) or $10.20 \%$ (dry basis). The pomace had a more even moisture content in the hot air oven than in the microwave oven because drying in hot air allowed the heat to diffuse into the pomace more slowly and evenly than drying in a 
microwave oven, while in the microwave oven, the pomace absorbed the microwave energy and turned it into heat, which spread throughout the pomace from a high temperature areas to low temperature areas. The pomace at the corners or edges was exposed to more intense microwave irradiation than that in other areas because the microwave radiation accumulated in that area, causing the pomace to become dryer than in other areas (Buffler, 1993). Therefore, pomace dried in a microwave oven had an uneven moisture content.

Table 3. The pectin yield from kaffir lime pomace dried in a hot air oven or a microwave oven and extracted in a water bath or a microwave oven

\begin{tabular}{|c|c|c|}
\hline \multirow{3}{*}{$\begin{array}{l}\text { Drying } \\
\text { method }^{\mathrm{NS}}\end{array}$} & \multicolumn{2}{|c|}{ Extraction method } \\
\hline & $\begin{array}{l}\text { Microwave oven } \\
(450 \mathrm{~W}, 20 \mathrm{~min})\end{array}$ & $\begin{array}{l}\text { Water bath } \\
\left(90^{\circ} \mathrm{C}, 1 \mathrm{hr}\right)\end{array}$ \\
\hline & \% dry basis & $\%$ dry basis \\
\hline $\begin{array}{l}\text { Hot air oven } \\
\left(55{ }^{\circ} \mathrm{C}, \quad 18\right. \\
\text { hr) }\end{array}$ & $33.28 \pm 1.85$ & $21.31 \pm 1.39$ \\
\hline $\begin{array}{l}\text { Microwave } \\
\text { oven } \\
(900 \mathrm{~W}, 20 \\
\min )\end{array}$ & $34.86 \pm 2.62$ & $23.33 \pm 1.26$ \\
\hline$\overline{\mathrm{x}} \pm$ S.D. & $34.07 \pm 2.20^{\mathrm{A}}$ & $22.32 \pm 1.62^{\mathrm{B}}$ \\
\hline $\begin{array}{l}\text { Significant } \\
\text { interaction }\end{array}$ & \multicolumn{2}{|l|}{ Significance } \\
\hline $\begin{array}{l}\text { Drying } \\
\text { method }\end{array}$ & \multicolumn{2}{|l|}{ NS } \\
\hline $\begin{array}{l}\text { Extraction } \\
\text { method }\end{array}$ & \multicolumn{2}{|l|}{$*$} \\
\hline \begin{tabular}{l}
\multicolumn{1}{c}{ Drying } \\
method $\times$ \\
Extraction \\
method
\end{tabular} & \multicolumn{2}{|l|}{ NS } \\
\hline
\end{tabular}

Values are mean \pm S.D. (three replicates)

NS and * indicate not significant and significant at $\mathrm{p}=0.05$, respectively.
The values in the same row followed by different superscript (A-B) were significantly different $(\mathrm{p}<0.05)$.

From Table 3, The interaction of the drying and extraction methods and the main factor was the drying method but it did not significantly affect the yield ( $\mathrm{p} \geq 0.05$ ), while the key factor was the extraction method, which did significantly affect the yield $(p<0.05)$. Extraction in a microwave oven yielded 1.50-fold more pectin than extraction in a water bath because the microwave radiation was converted to heat by the vibration of the charged particles or the rotation of polar molecules, causing them to collide with nearby molecules after the object was exposed to a microwave radiation and absorbed the energy. As a result, heat was generated quickly. Therefore, the heat was distributed evenly, which caused a higher yield. Heating in a water bath was different; the heat was transferred from high temperature areas to the low temperature areas from the hot water in the bath into the samples that adhered to the wall of the beaker. The heat was subsequently transferred to the samples in the center of the beaker by thermal conduction and convection. A comparison of the yield of pectin extracted from pomace dried in a microwave oven and a water bath revealed that the yield was $23.33 \%$ (dry basis), which was less than that obtained by Shaha et al. (2013) who extracted pectin from kaffir lime peel and obtained a $37.00 \%$ yield. Maran et al. (2013) extracted pectin from orange peel and obtained a $19.24 \%$ yield. The yields differences were due to the different raw materials, extraction methods, and extraction conditions.

The pectin yield from pomace dried in a microwave oven $(900 \mathrm{~W}, 20 \mathrm{~min})$ and extracted in a microwave oven $(450 \mathrm{~W}, 20$ min) was the highest at $34.86 \%$ (dry basis), but it was not significantly different from pomace dried in a hot air oven $\left(55^{\circ} \mathrm{C}, 18 \mathrm{~h}\right)$ 
and extracted in a microwave oven $(450 \mathrm{~W}$, 20 min) which had a yield of $33.28 \%$ (dry basis) (see Table 3).

\subsection{Optimum conditions for the highest yield from kaffir lime pomace extracted in a microwave oven and the equation for predicting the yield}

Table 4. Analysis of variance of regression model in terms of four independent variables (Actual value) for yield of pectin

\begin{tabular}{|l|l|l|l|l|l|l|}
\hline & F & Seq SS & Adj SS & $\begin{array}{l}\text { Adj } \\
\text { MS }\end{array}$ & F & P \\
\hline \hline Regression & 9 & 460.064 & 460.064 & 51.118 & 7.02 & $0.022^{*}$ \\
\hline Linear & 3 & 80.663 & 80.663 & 26.888 & 3.69 & 0.097 \\
\hline Square & 3 & 249.721 & 249.721 & 83.24 & 11.43 & $0.011^{*}$ \\
\hline Interaction & 3 & 129.68 & 129.68 & 43.227 & 5.94 & $0.042^{*}$ \\
\hline $\begin{array}{l}\text { Residual } \\
\text { Error }\end{array}$ & 5 & 36.405 & 36.405 & 7.281 & & \\
\hline Lack-of-Fit & 3 & 29.236 & 29.236 & 9.745 & 2.72 & 0.280 \\
\hline Pure Error & 2 & 7.169 & 7.169 & 3.584 & & \\
\hline Total & 1 & 496.469 & & & & \\
\hline
\end{tabular}

Note: * Significant at $\mathrm{p}<0.05$.

$\mathrm{DF}=$ The degrees of freedom of an estimate of a parameter

Seq SS = The sequential sum of squares for each term in the model

Adj SS $=$ The adjusted sum of squares for a term in the model

Adj $\mathrm{MS}=$ The adjusted mean square $=$ Adj SS/DF

Table 4 shows that the linear and quadratic effect of the three independent variables (the ratio of the pomace powder to distilled water, $\mathrm{pH}$, and pectin extraction time) played a significant role in the yield of pectin $(\mathrm{p}<0.05)$, and the lack of fit was equal to $0.280, \mathrm{p} \geq 0.05$ ), indicating no significant difference, which meant that the equation did not have a significant lack of fit or that the equation fit the experimental results well. Therefore, the equation (1) was suitable to predict the yield from the microwave-assisted extraction of kaffir lime pomace.

Equation for Predicting Yield: $Y=28.4887-\left(2.7147 x_{1}\right)+\left(1.6238 x_{2}\right)-\left(0.276 x_{3}\right)$

$$
-\left(4.6388 x_{1}^{2}\right)-\left(4.3759 x_{2}^{2}\right)-\left(6.0787 x_{3}^{2}\right)-
$$$$
\left(0.7844 x_{1} x_{2}\right)+\left(5.2704 x_{1} x_{3}\right)+\left(2.0068 x_{2} x_{3}\right)
$$

$\mathrm{R}^{2}=92.67 \%$

where

$Y$ is the yield (\% wet basis)

$x_{1}$ is the ratio of kaffir lime pomace powder to distilled water in coded units (value -1 to 1 )

$x_{2}$ is $\mathrm{pH}$ in coded units (value -1 to 1 )

$x_{3}$ is extraction time in coded units (value -1 to 1$)$

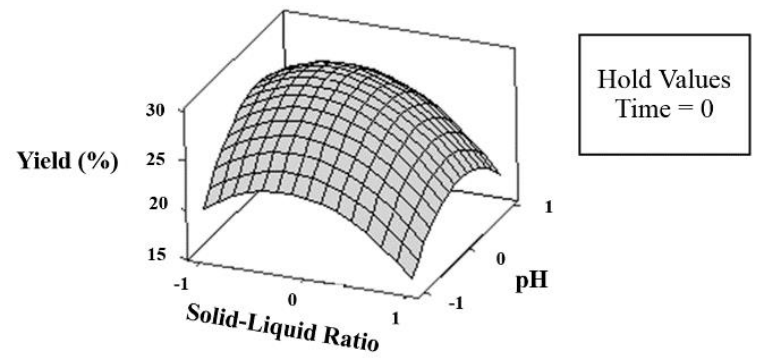

Figure 2. Three-dimensional graph of the yield from a microwave-assisted pectin extraction from pomace $(Y)$ at various pomace to water ratios $\left(x_{1}\right)(\mathrm{g} / \mathrm{mL})$ and $\mathrm{pH}$ $\left(x_{2}\right)$ by using microwave power at $450 \mathrm{~W}$ for $20 \min \left(x_{3}=0\right)$

Figure 2, shows the major factors that influenced the yield were the pomace to water ratio and the $\mathrm{pH}$. When the pomace to water ratio was less than 1 to 16.5 (code = 0.75 ) and higher than 1 to $33.6 \mathrm{~g} / \mathrm{mL}$ (code = $-0.2)$ and the $\mathrm{pH}$ was below $1.35(\operatorname{code}=-0.3)$ and above 1.88 (code $=0.75$ ) the yield was lower. If the pomace to water ratio $\left(x_{1}\right)$ is lower, more solution is necessary to extract the pectin and thus more pectin is produced. A larger concentration gradient resulting from the higher solvent to solid ratio during the diffusion of the internal material into the solution would accelerate the mass transfer, thereby increasing the extraction efficiency. Too much or a too dilute solution would lower the yield. If too little solution is used for extraction, it will not be enough to extract 
the pectin from the cells (Guo et al., 2001). The $\mathrm{pH}\left(x_{2}\right)$ affected the pectin extraction by facilitating the extraction of the pectin from the cells, thus increasing the extraction efficiency (El-Nawawi and Shehata, 1988). Pectin is solubilized in two steps. First, the pectin is depolymerized via a $\beta$-elimination reaction that occurs when heated at a neutral or weakly acidic $\mathrm{pH}$, causing the molecules to be small enough to solubilized from the cell walls. In the second step, the pectin is degraded by a thermal process due to acid hydrolysis $(\mathrm{pH}<3)$ (Sila et al., 2009). Pectin is very stable at approximately $\mathrm{pH} 3.5$, which is its pKa (Sila et al., 2009). At a pomace to water ratios ratio of $1: 16.5$ (Coded value $=$ 0.75 ) to $1: 33.6 \mathrm{~g} / \mathrm{mL}$ (Coded value $=0.2)$ and $\mathrm{pH} 1.35($ Coded value $=-0.3)$ to $1.88($ Coded value $=0.75)$, the yield was the highest at $29.21 \%$.

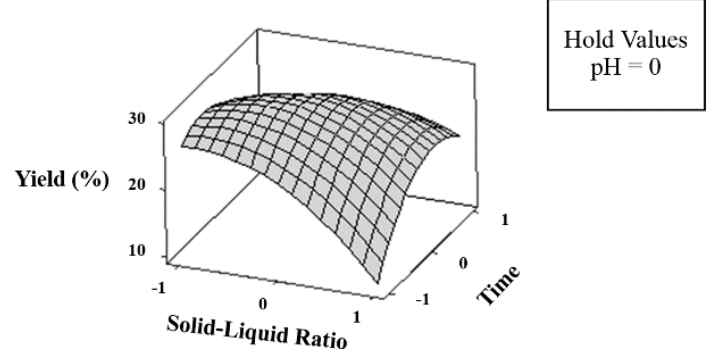

Figure 3. Three-dimensional graph of the yield from the microwave-assisted pectin extraction from pomace $(Y)$ at various pomace to water ratios $\left(x_{1}\right)(\mathrm{g} / \mathrm{mL})$ and extraction times $\left(x_{3}\right)$ at $450 \mathrm{~W}$ and $\mathrm{pH} 1.5\left(x_{2}\right.$ $=0$ )

Figure 3 shows that the pomace to water ratio and the extraction time were the key factors that affected the yield. Time affects the absorption of the microwave energy in the extraction process before it is transformed into heat in the extracting solution. Thus, a longer time would yield higher pectin. However, excessive time produces excessive heat; therefore, thermal pectin hydrolysis could occur, lowering the yield (Xianzhe et $a l ., 2011)$. At pomace to water ratios of
$1: 13.8($ code $=-0.9)$ to $1: 33.6 \mathrm{~g} / \mathrm{mL}($ code $=$ 0.2 ) and extraction times of $13 \mathrm{~min}$ (code = 0.7 ) to $23 \mathrm{~min}$ (code $=0.3$ ), the yield would be the highest at $29.21 \%$.

At pH $1.35($ code $=-0.3)$ to $1.88($ code $=$ 0.75 ) and an extraction time of 16 min (code $=-0.4$ ) to $24.9 \min ($ code $=0.49)$, the yield would be the highest at $29.21 \%$. If the $\mathrm{pH}$ and extraction time are higher or lower than in the appropriate range, the yield will be lower (Figure 4).

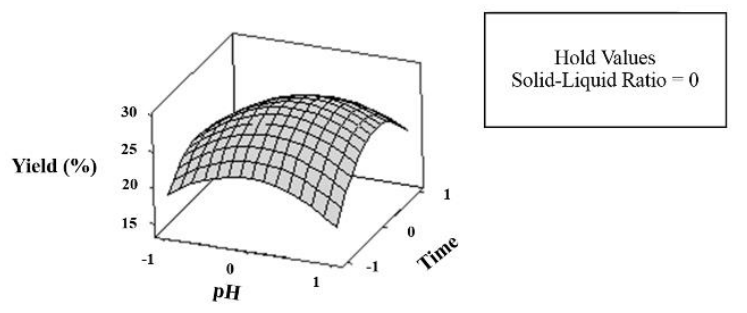

Figure 4. Three-dimensional graph of yield from microwave-assisted pectin extraction from pomace $(Y)$ at various $\mathrm{pH}\left(x_{2}\right)$ and extraction times $\left(x_{3}\right)$ at $450 \mathrm{~W}$ and a pomace to water ratio of $1: 30 \mathrm{~g} / \mathrm{mL}\left(x_{1}=0\right)$

\subsection{Validation of a Mathematical Model}

From the optimum conditions obtained from the Minitab 16 software, the mathematical model was validated with experiments using microwave-assisted pectin extraction from pomace (the condition used were a pomace to water ratio of $1: 23, \mathrm{pH} 1.6$, and an extraction time of $18 \mathrm{~min}$ at $450 \mathrm{~W}$ ).

There experiments were performed in triplicate. A yield of $28.89 \pm 1.25 \%$ was obtained. When compared to the values obtained from the model of $29.20 \%$, the difference was $1.06 \%$, which was similar, indicating that the model can predict the percentage yield well.

\subsection{Study of physical and chemical properties of extracted pectin}

A pomace powder sample dried in a hot air oven to a moisture content of $10.20 \pm$ 
$0.24 \%$ (dry basis) was extracted in a water bath and microwave oven to study the physical and chemical properties of the pectin obtained. The results are shown in Table 5.

Table 5. Physical and chemical properties of pectin

\begin{tabular}{|c|c|c|c|}
\hline $\begin{array}{l}\text { Physical \& } \\
\text { chemical } \\
\text { properties }\end{array}$ & $\begin{array}{l}\text { Commercial } \\
\text { pectin }^{x}\end{array}$ & $\begin{array}{l}\text { Pectin } \\
\text { dried with } \\
\text { hot air and } \\
\text { extracted } \\
\text { with } \mathbf{m w}^{\mathrm{Y}}\end{array}$ & $\begin{array}{l}\text { Pectin } \\
\text { dried with } \\
\text { hot air } \\
\text { oven and } \\
\text { extracted } \\
\text { with water } \\
\text { bath }^{\mathrm{Z}}\end{array}$ \\
\hline \multicolumn{4}{|l|}{ Color value } \\
\hline$L^{*}$ & $82.64 \pm 0.02^{\mathrm{A}}$ & $\begin{array}{ll}50.04 & \pm \\
0.03^{\mathrm{B}} & \\
\end{array}$ & $\begin{array}{ll}43.14 & \pm \\
0.05^{\mathrm{C}} & \\
\end{array}$ \\
\hline$a^{*}$ & $3.21 \pm 0.02^{\mathrm{A}}$ & $\begin{array}{ll}1.36 & \pm \\
0.01^{\mathrm{B}} & \end{array}$ & $0.26 \pm 0.01^{\mathrm{C}}$ \\
\hline$b^{*}$ & $14.12 \pm 0.04^{\mathrm{A}}$ & $\begin{array}{l}12.00 \\
0.03^{\mathrm{B}}\end{array}$ & $\begin{array}{l}10.78 \\
0.04^{\mathrm{C}}\end{array}$ \\
\hline$C^{*}$ & $14.49 \pm 0.03^{\mathrm{A}}$ & $\begin{array}{l}12.08 \\
0.03^{\mathrm{B}}\end{array}$ & $\begin{array}{l}10.78 \\
0.04^{\mathrm{C}}\end{array}$ \\
\hline$h^{*}$ & $77.18 \pm 0.05^{\mathrm{C}}$ & $\begin{array}{l}83.53 \\
0.06^{\mathrm{B}}\end{array}$ & $\begin{array}{ll}88.64 & \pm \\
0.03^{\mathrm{A}} & \end{array}$ \\
\hline $\begin{array}{l}\text { Moisture } \\
\text { content by dry } \\
\text { basis }(\%)\end{array}$ & $9.55 \pm 0.28^{\mathrm{B}}$ & $\begin{array}{l}9.57 \\
0.18^{\mathrm{B}}\end{array}$ & $\begin{array}{ll}11.66 & \pm \\
0.40^{\mathrm{A}} & \end{array}$ \\
\hline $\begin{array}{l}\text { Ash content by } \\
\text { dry basis }(\%)\end{array}$ & $2.05 \pm 0.04^{\mathrm{C}}$ & $\begin{array}{ll}2.85 & \pm \\
0.03^{\mathrm{A}} & \end{array}$ & $2.27 \pm 0.04^{\mathrm{B}}$ \\
\hline $\begin{array}{l}\text { Equivalent } \\
\text { weight } \\
\text { (g) }\end{array}$ & $\begin{array}{l}1066.12 \pm \\
1.55^{\mathrm{A}}\end{array}$ & $\begin{array}{l}526.87 \quad \pm \\
1.61^{\mathrm{B}}\end{array}$ & $\begin{array}{l}475.89 \\
\pm 1.50^{\mathrm{C}}\end{array}$ \\
\hline $\begin{array}{l}\text { Methoxyl } \\
\text { content } \\
(\%)\end{array}$ & $13.67 \pm 0.02^{\mathrm{A}}$ & $\begin{array}{l}10.46 \\
0.02^{\mathrm{B}}\end{array}$ & $9.78 \pm 0.02^{\mathrm{C}}$ \\
\hline $\begin{array}{l}\text { A.U.A. content } \\
(\%)\end{array}$ & $94.14 \pm 0.09^{\mathrm{A}}$ & $\begin{array}{l}92.79 \\
0.21^{\mathrm{B}}\end{array}$ & $\begin{array}{l}92.52 \\
0.20^{\mathrm{B}}\end{array}$ \\
\hline $\begin{array}{l}\text { Degree of } \\
\text { esterification } \\
(\%)\end{array}$ & $82.46 \pm 0.03^{\mathrm{A}}$ & $\begin{array}{l}64.00 \\
0.03^{\mathrm{B}}\end{array}$ & $\begin{array}{l}60.03 \\
0.06^{\mathrm{C}}\end{array}$ \\
\hline
\end{tabular}

Note A, B, C indicate the average of horizontal data is significantly different $(\mathrm{p}<0.05) \quad(\mathrm{n}=3)$

$\mathrm{X}$ commercial food grade pectin (Apple Pectin AP104 HP, China)

$Y$ Pectin dried with hot air oven and extracted with microwave oven. Extraction conditions were a pomace to water ratio of $1: 23 \mathrm{w} / \mathrm{v}, \mathrm{pH} 1.6$, an extraction time of 18 min, and $450 \mathrm{~W}$ (the optimum conditions obtained in this study).

$\mathrm{Z}$ Pectin dried with hot air oven and extracted with water bath. Extraction conditions were a pomace to water ratio of
1:40 w/v, $\mathrm{pH} 1.5$, extraction time of $1 \mathrm{~h}$, and a water bath temperature of $90{ }^{\circ} \mathrm{C}$ (Shaha et al., 2013).

From Table 5, it was found that the color value of the pectin varied significantly $(\mathrm{p}<0.05)$. The results indicate that $L^{*}, a^{*}, b^{*}$, and $C^{*}$ values for the high methoxyl commercial pectin were higher than those of the pectin from the pomace extracted in a water bath and the pectin from the pomace extracted in a microwave oven. The color of pectin from this research was green shade.

Because of the residual color from kaffir lime peel.

The ash content indicates the pectin quality. A higher ash content indicates more contaminants in the pectin. Good quality pectin must have low ash content. Related research has also found that the ash contents of the extracted pectin were between 2.88.5\%. Pagan and Ibarz (1999) showed an ash content of pectin extracted from peach peel of $3.0 \pm 0.2 \%$ and Pagan et al. (2001) showed an ash content of pectin extracted from peach peel at $2.8 \pm 0.3 \%$.

The equivalent weight is the amount in grams of pure polygalacturonic acid. It depends on the degree of esterification, which is correlated with the number of free carboxylic groups in one gram mole equivalent to one gram mole of hydroxy. It can be obtained by titration with sodium hydroxide (Ranganna, 1997). The equivalent weights of the pectin from pomace extracted in a water bath and the pectin from pomace extracted in a microwave oven in this study were similar to that of Shaha et al. (2013), who extracted pectin from kaffir lime peel and obtained an equivalent weight of 210 $735.4 \mathrm{~g}$.

The methoxyl content is an important variable that determines the gelation time of the pectin and the sensitivity of its response to polyvalent cations. If the methoxyl content is high, it indicates that that the pectin will gel 
quickly. The methoxyl content of all 3 samples was higher than $9 \%$.

The anhydrouronic acid (A.U.A.) content indicates the purity of pectin because the main component of pectin is esterified polygalacturonic acid. Table 5 shows that the A.U.A. content of the pectin from pomace extracted in a water bath and the pectin from pomace extracted in a microwave oven were similar to values obtained by Shaha et al. (2013), which had an A.U.A. content of 38$98 \%$, but a comparison with the A.U.A. content of commercial pectin with the pectin from pomace indicated that the pectin from pomace had a significantly lower A.U.A. contents than commercial pectin $(p<0.05)$.

The degree of esterification of all 3 samples was higher than $50 \%$, so they were categorized as high methoxyl pectins and had a degree of esterification according to the FDA standard of at least $50 \%$ degree of esterification. The degree of esterification of pectin extracted in a water bath and extracted in a microwave oven were similar to that obtained by Shaha et al. (2013), which had a degree of esterification of 58-65\%.

Pectin extracted in a microwave oven had chemical properties similar to pectin extracted in a water bath, and when comparing the chemical properties of the 2 samples with those of the commercial pectin, it was found that pectin extracted in the microwave oven had chemical properties more similar to those of commercial pectin.

\section{Conclusions}

The best method for pectin extraction from pomace was in a microwave oven because it produced an average yield approximately $35 \%$ higher than extraction in a water bath (the average yields of pectin extracted in a water bath and in a microwave oven were $22.32 \pm 1.32$ and $34.07 \pm 2.20$, respectively.

The optimum conditions for using microwave radiation to facilitate pectin extraction from pomace to obtain the highest yield of $29.20 \%$ was a pomace to water ratio of $1: 23$, a $\mathrm{pH}$ of 1.6 , and an extraction time of $18 \mathrm{~min}$ at $450 \mathrm{~W}$.

The pectin extracted from pomace dried in a hot air oven and extracted in a microwave oven had light green color, a moisture content of $9.57 \pm 0.18 \%$ (dry basis), an ash content of $2.85 \pm 0.03 \%$, an equivalent weight of 526.87 $\pm 1.61 \mathrm{~g}$, a methoxyl content of $10.46 \pm$ $0.02 \%$, an A.U.A. content of $92.79 \pm 0.21 \%$, and a degree of esterification of $64.00 \pm$ $0.03 \%$. The pectin extracted in this study can be categorized as high methoxyl pectin.

\section{References}

Buffler, C.R. (1993). Microwave Cooking and Processing. Engineering

Fundamental for the Food Scientist. Van Nostrand Reinheld, New York.

El-Nawawi, S.A., Shehata, F.R.F.R. (1988). Effect of the Extraction Temperature on the Characteristics of Pectin Extracted from Egyptian Orange Peel. Biological Wastes, 24, 307-311.

Guo, Z.K., Jin, Q.H., Fan, G.Q., Duan, Y.P., Qin, C., Wen, M.J. (2001). Microwave Assisted Extraction of Effective Constituents from a Chinese Herbal Medicine Radix Puerariae. Analytica Chimica Acta, 436, 41-47.

Koseki, M., Kitabatake, N., Doi, E., Yasuno, T., Ogino, S., Ito, A., Endo, F. (1986).

Determination of Pectin in the Presence of Food Polysaccharide. Journal of food science, 51(5), 1329-1332.

Li, D.Q., Jia, X., Wei, Z., Liu, Z.Y. (2012). Box-Behnken Experimental Design for Investigation of Microwave-Assisted Extracted Sugar Beet Pulp Pectin. Carbohydrate Polymers, 88, 342-346. 
Maran, J.P., Prakash, K.A. (2015). Process Variables Influence on Microwave Assisted Extraction of Pectin from Waste Carcia papaya L. peel. International Journal of Biological Macromolecules, 73, 202-206.

Maran, J.P., Sivakumar, V., Thirugnanasambandham, K., Sridhar, R. (2013). Optimization of Microwave Assisted Extraction of Pectin from Orange Peel. Carbohydrate Polymers, 97, 703-709.

Maran, J.P., Sivakumar, V., Thirugnanasambandham, K., Sridhar, R. (2014). Microwave Assisted Extraction of Pectin from Waste Citrullus lanatus Fruit Rinds. Carbohydrate Polymers, 101, 786-791.

Maran, J.P., Swathi, K., Jeevitha, P., Jayalakshmi, J., Ashvini, G. (2015). Microwave-Assisted Extraction of Pectin Polysaccharide from Waste Mango Peel. Carbohydrate Polymers, 123, 67-71.

McCready, R.M. Pectin. Cited in Joslyn, M.A. (1954). Methods in Food Analysis. A Subsidiary of Harcourt Brace Jovanovich, Publishers. New York.

Mohamed, S., Hasan, Z. (1995). Extraction and Characterization of Pectin from Various Tropical Agrowastes. ASEAN Food Journal, 2, 43-50.

Owens, H.S., McCready, R.M., Shepard, A.D., Schultz, T.H., Pippen, E.L., Swenson, H.A., Miers, J.C., Erlandsen, R.F., Maclay, W.D. (1952). Methods Used at Western Regional Research Laboratory for Extraction of Pectin Materials. Bureau of Agricultural and Industrial Chemistry, Agricultural Research Administration. USA.
Pagan, J., Ibarz, A. (1999). Extraction and Rheological Properties of Pectin from Fresh Peach Pomace. Journal of Food Engineering, 39, 193 - 201.

Pagan, J., Ibarz, A., Llorca, M., Pagan, A., Barbosa - Canovas, G.V. (2001). Extraction and Characterization of Pectin from Stored Peach Pomace. Food Research International, 34(7), 605-612.

Ranganna, S. (1995). Handbook of Analysis of Quality Control for Fruit and Vegetable Products. Tata McGraw Hill Publishing Company Limited. New delhi.

Ranganna, S. (1997). Manual of Analysis of Fruit and Vegetable Product. $2^{\text {nd }}$ ed. Tata McGraw Hill Pulblishing Company Limited. New delhi.

Shaha, R.K., Punichelvana, Y.N.A.P., Afandi, A. (2013). Optimized Extraction Condition and Characterization of Pectin from Kaffir Lime (Citrus hystrix). Research Journal of Agriculture and Forestry Science, 1(2), 1-11.

Sila, D.N., Van Buggenhout, S., Duvetter, T., Fraeye, I., De Roeck, A., Van Loey, A., Hendrickx, M. (2009). Pectin in Processed Fruits and Vegetables: Part IIStruture - Function Relationships. Comprehensive Reviews in Food Science and Food Safety, 8, 86-104.

Thakur, B.R., Singh, R.K. Handa, A.K., Rao, M.A. (1997). Chemistry and uses of pectin - A review. Critical Reviews in Food Science and Nutrition, 37(1), 4773.

The Association of Official Analytical Chemists. (2000). Official Method of Analysis. $\quad 17^{\text {th }}$ ed. Gaithersburg, Maryland. 
Thirugnanasambandham, K., Sivakumar V., Maran P.J. (2014). Process Optimization and Analysis of Microwave Assisted Extraction of Pectin from Dragon Fruit Peel. Carbohydrate Polymers, 112, 622626.

Voragen, A.G.J., Pilnik, W., Thaibault, J.F., Axelos, M.A.V., Renard, C.M.C.G. (1995). Food Polysaccharides and Their Applications. Marcel Dekker. New York. Wang, S., Chen, F., Wu, J., Wang, Z., Liao, X., Hu, X. (2007). Optimization of Pectin Extraction Assisted by Microwave from Apple Pomace Using Response Surface Methodology. Journal of Food Engineering, 78, 693-700.

Xianzhe, Z., Fangping, Y., Chenghai, L., Xiangwen, X. (2011). Effect of Process Parameters of Microwave Assisted Extraction (MAE) on Polysaccharides Yield from Pumpkin. Journal of Northeast Agricultural University, 8(2), 79-86.

\section{Acknowledgment}

This research was funded by King Mongkut's University of Technology North Bangkok. Contract no. KMUTNB-GEN-5931. 